\title{
Phylogeography of the weasel (Mustela nivalis) in the western-Palaearctic region: combined effects of glacial events and human movements
}

\author{
C Lebarbenchon ${ }^{1,2}, \mathrm{~F}$ Poitevin ${ }^{3}, \mathrm{~V} \mathrm{Arnal}^{3}$ and C Montgelard ${ }^{3}$ \\ ${ }^{1}$ Génétique et Évolution des Maladies Infectieuses, UMR CNRS/IRD 2724, IRD—911 avenue Agropolis, Montpellier cedex 5, France; \\ ${ }^{2}$ Centre de Recherche de la Tour du Valat, Le Sambuc, Arles, France and ${ }^{3}$ Biogéographie et Écologie des Vertébrés (EPHE), Centre \\ d'Écologie Fonctionnelle et Évolutive (UMR 5175 CNRS), 1919 route de Mende, Montpellier cedex 5, France
}

\begin{abstract}
The Iberian, Italian or Balkan peninsulas have been considered as refugia for numerous mammalian species in response to Quaternary climatic fluctuations in Europe. In addition to this 'southerly refugial model', northern refugia have also been described notably for generalist and coldtolerant species. Here, we investigated the phylogeographic pattern of the weasel (Mustela nivalis) to assess the impact of Quaternary glaciations on the genetic structure, number and location of refugia as well as to determine the impact of human movements on the colonization of Mediterranean islands. We sequenced $1690 \mathrm{bp}$ from the mitochondrial control region and cytochrome $b$ for 88 weasels distributed throughout the western-Palaearctic region, including five Mediterranean islands. Phylogenetic analyses of combined genes produced a clear phylogeographic pattern with two main lineages. The first lineage included all of the
\end{abstract}

western-continental samples (from Spain to Finland) and shows low levels of genetic structure. Demographic analysis highlighted several characteristics of an expanding group, dated approximately at 116 kiloyears (kyr; Riss glaciation). The genetic pattern suggested a northeastern-European origin from which colonization of southwestern Europe took place. The second lineage was divided into five subgroups and indicated a common origin of insular and Moroccan samples from eastern Europe. Eastern-continental weasels did not exhibit signs of sudden expansion, suggesting stable population size during the last ice ages. The time of expansion of Sicilian and Corsican populations was dated around $10 \mathrm{kyr}$ ago, which supports the hypothesis of an early human intervention in the colonization of Mediterranean islands.

Heredity (2010) 105, 449-462; doi:10.1038/hdy.2009.186; published online 20 January 2010

Keywords: mitochondrial control region; cytochrome b; Mediterranean islands; Quaternary glaciations; molecular dating; intraspecific taxonomy

\section{Introduction}

Phylogeographic patterns reported for numerous mammalian species in Europe are often interpreted as the consequences of the Quaternary climatic fluctuations, and the southern-European peninsulas (Iberian, Italian or Balkan regions) have been identified as refugia where flora and fauna survived during glacial phases (Taberlet et al., 1998; Hewitt, 2000, 2004). If a number of European taxa conformed to this now classical interpretation (see review in Hewitt, 2004; Randi, 2007), several studies indicated that this 'southerly refugial model' (Bhagwat and Willis, 2008) is probably too simplistic and not satisfactory for some taxa. Alternative concepts have been developed involving the existence of northern refugia (Stewart and Lister, 2001; Kotlik et al., 2006; Bhagwat and Willis, 2008; Tougard et al., 2008), microrefugia (small favourable areas outside the main

Correspondence: Dr C Montgelard, Laboratoire de Biogéographie et Écologie des Vertébrés (EPHE), Centre d'Ecologie Fonctionnelle et Evolutive (UMR 5175 CNRS), 1919 route de Mende, Montpellier cedex 5 34095, France.

E-mail: claudine.montgelard@cefe.cnrs.fr

Received 3 June 2009; revised 27 November 2009; accepted 11

December 2009; published online 20 January 2010 refugium; Rull, 2009) or nunatak vs lowland refugia (specific to mountain species; Holderegger and Thiel-Egenter, 2009). According to Bhagwat and Willis (2008), populations not originating from southern refugia present common biogeographical traits, such as a small body size, a present-day northerly distribution and they are cold-tolerant animals. Among European mammals, several species of Mustelidae display such characteristics that would have allowed them to persist in northerly areas. However, phylogeographic studies conducted on Mustelidae are few and mostly inconclusive. The study of Davison et al. (2001) on Martes martes and Mustela putorius and the work of Ferrando et al. (2004) on Lutra lutra showed a lack of structuring and ancient lineages explained by an expansion from a single, but not localized, European refugium. For $M$. erminea, low genetic differentiation and structure were observed among continental Eurasian populations, with only one lineage from Europe (Ireland excepted) to Japan up to Alaska whose origin is not specified (Fleming and Cook, 2002; Kurose et al., 2000, 2005; Martinkova et al., 2007). Finally, the phylogeographical analysis of Meles meles across Eurasia (Marmi et al., 2006) evidenced four genetic groups, but only one lineage in Europe possibly resulting from postglacial recolonization from several refugia. 
In this study, phylogeographic variations in the western-Palaearctic region and genetic diversification related to Quaternary climatic changes are investigated for the weasel (Mustela nivalis, Linnaeus 1766). This species has a wide distribution covering nearly the entire Holarctic area (Europe, North Africa, northern Asia and North America). It is widespread throughout the entire western-Palaearctic region, with the exception of several Atlantic islands (including Ireland, Iceland and the Canary Islands). The species displays considerable variability across this wide geographic range. Consequently, there is a wealth of literature concerning the identification and description of different weasel lineages in Europe (three or four subspecies are described in Europe and North Africa), mainly based on morphological variations (Frank, 1985; Meia and Mermod, 1992; Zyll De Jong, 1992; Abramov and Baryshnikov, 2000) and chromosomal patterns (Zima and Cenevova, 2002). In contrast, molecular studies are scarce and mainly concern Japanese and Eurasian regions (Kurose et al., 1999, 2005; Saarma and Tumanov, 2006). In western Europe, two lineages have been recognized (Lebarbenchon et al., 2006), one in the mainland (France, Italy) and one in Corsica. However, these studies are based on short sequences (partial cytochrome $b(c y t b)$ or control region $(c t r)$ ) and include only a few individuals. This precludes a clear estimation of the number of genetic groups as well as their possible origin and relationships. Finally, the study of Lebarbenchon et al. (2006) raised the question of the origin of the two genetic lineages observed for $M$. nivalis in a broader phylogeographic context at the European scale.

The second aim of our study concerns the colonization of Mediterranean islands. Several mammalian species have been studied to identify the genetic link between insular and mainland populations (Santucci et al., 1998; Pierpaoli et al., 1999; Cosson et al., 2005; Dubey et al., 2007a, 2008). From these and other studies, it can be concluded that modalities of island colonization are very diverse according to the island and/or species under study, leading to a complex pattern of mammalian composition representing endemic, native or introduced species (Masseti, 1998; Sarà, 1998).

$M$. nivalis is one of the most common mustelids occurring in the islands of the Palaearctic region, inhabiting all Mediterranean islands larger than $240 \mathrm{~km}^{2}$ with the exception of Ibiza and Cyprus (Masseti, 1995; De Marinis and Masseti, 2003). As is often reported for small mammals (Blondel and Vigne, 1993; Alder and Levins, 1994; Michaux et al., 2002), insular and mainland populations of $M$. nivalis differ morphologically. These variations include larger body size and darker coat colouration in insular populations (Beaucournu and Grulich, 1968; Alcover and Jaume, 1983) and led to the description of potentially one subspecies per island (Beaucournu and Grulich, 1968; De Marinis, 1996). For M. nivalis, the prevalent hypothesis is a colonization through human introduction (Masseti, 1995; Bover and Alcover, 2008). Until now, no genetic study has been performed to identify the geographic origin of insular weasel populations or to determine the impact of human movements on the presence of this species in the Mediterranean islands.

We used mitochondrial partial $c t r$ and complete $c y t b$ sequences to investigate the genetic variation and phylogeographic pattern of the weasel in the westernPalaearctic region (from Morocco to Finland) including five Mediterranean islands (Minorca, Corsica, Sardinia, Sicily and Crete). On the basis of this dataset, specific objectives concerning the phylogeography of the weasel were addressed: (1) evaluate the impact of the Quaternary glacial cycles on the genetic diversity of weasels by dating the origin of the phylogenetic groups, (2) infer the locations of potential glacial refugia, (3) assess the demographic history of phylogenetic clades, (4) determine whether colonization of Mediterranean islands occurs through human intervention or natural migration and (5) compare current taxonomic classification with genetic groups.

\section{Materials and methods}

\section{Sampling}

We sequenced a total of 88 weasels distributed in the western-Palaearctic region (Figure 1). Our samples come from road-killed animals, museums or personal collections (Table 1). We added published sequences from the European Molecular Biology Laboratory Database for weasels of the western-Palaearctic region. Thus, six ctr and nine $c y t b$ (two complete and seven partial sequences; see Table 1) have been added to our dataset. Moreover, five other species of Mustela were used as outgroups: the western polecat $M$. putorius, the steppe polecat $M$. eversmanni, the European mink M. lutreola, the Japanese weasel $M$. itatsi and the stoat $M$. erminea (see Table 1 for accession numbers and references).

\section{DNA sequencing and alignment}

DNA was extracted from skin samples from the ear (frozen or preserved in ethanol) using the QIAamp DNA Mini Kit (Qiagen, Courtaboeuf, France). The first 550 nucleotides of the $5^{\prime}$ portion of the mitochondrial ctr were amplified using the L0Mni $5^{\prime}$-GCC CCR CCA TCA GCA CCC AAA GC-3' (this study from weasel ctr alignment) and MSD (Kurose et al., 1999) primers. In case DNA was degraded, we used two internal primers (L1Mni 5'-ACC TCT TCT CGC TCC GGG CCC ATC A-3'; this study from weasel ctr alignment and E3 (Arnason et al., 1997) to amplify ctr in two overlapping fragments of 306 and 363 nucleotides. The mitochondrial DNA cytb gene was amplified entirely using L7 and H6 primers (Montgelard et al., 2002) or in two overlapping fragments (767 and $742 \mathrm{bp}$ ) with the internal primers H2 and L2 (Hassanin et al., 1998). All weasels have been sequenced for the ctr (65 from this study and 23 from an earlier study by Lebarbenchon et al., 2006). For the $c y t b, 68$ samples have been sequenced, representing at least one individual from each geographic area and for each ctr haplotype. A total of 133 new sequences were obtained and deposited in the European Molecular Biology Laboratory Database with accession numbers given in Table 1.

For both genes, polymerase chain reaction was performed using an initial denaturation of $3 \mathrm{~min}$ at $94{ }^{\circ} \mathrm{C}$, followed by 35 cycles of $45 \mathrm{~s}$ denaturation at $94{ }^{\circ} \mathrm{C}$, $1 \mathrm{~min}$ annealing at $50^{\circ} \mathrm{C}, 2 \mathrm{~min}$ extension at $72{ }^{\circ} \mathrm{C}$ and a $10 \mathrm{~min}$ final extension at $72^{\circ} \mathrm{C}$. Polymerase chain reaction products were purified with a QIAquick polymerase chain reaction Gel Extraction Kit (Qiagen). Sequencing was carried out with an ABI Prism Big Dye Terminator 
Cycle Sequencing Ready Reaction Kit on an ABI Prism 310 Genetic Analyser (Applied Biosystems, Courtaboeuf, France). Electrophoregrams were read and aligned manually using Sequence Navigator software (Applied Biosystems).

The $c t r$ and $c y t b$ sequences were aligned by hand using ED editor of the MUST package (Philippe, 1993). The $c y t b$ was translated into protein and did not reveal any stop codons, suggesting that functional sequences were obtained. Indels present in the ctr alignment were considered as missing characters. The number of variable and informative sites was calculated using DNASP 4.50.2 software (Rozas et al., 2003).

\section{Genetic variability and population structure}

Genetic variability was estimated for both phylogenetic and geographic groups. The number of different haplotypes $\left(n_{\mathrm{H}}\right)$, haplotype diversity $(h)$ and nucleotide diversity $(\pi)$ as well as the average number of nucleotide differences $(k)$ within groups were estimated using DNASP program. The hypothesis of recent population growth was tested using different statistical tests. Deviation from neutrality of mutations was tested with Fu's Fs (Fu, 1997), Tajima's D statistic (Tajima, 1989) and $R_{2}$ test (Ramos-Onsins and Rozas, 2002) implemented in
DNASP. The significance of deviation was evaluated with 10000 boostrap replicates (constant population size for $P$-values $>0.05)$. Pairwise mismatch distributions of substitution differences were used to test for demographic expansion. Observed and expected values were compared with Arlequin 2.0 (Schneider et al., 2000) with 100 bootstrap replicates (demographic expansion rejected for $P$-values <0.05). Relationships between unique haplotypes were described by a parsimony network constructed with the program TCS 1.21 (Clement et al., 2000).

\section{Saturation and phylogenetic analyses}

Saturation of nucleotide substitutions was evaluated according to the procedure of Philippe et al. (1994). The inferred number of substitutions in maximum likelihood (programs PHYML version 2.4.4; Guindon and Gascuel, 2003 and Treeplot of MUST) was plotted against the pairwise number of observed differences between sequences (programs Comp_mat and Treeplot of MUST). The slope of the linear regression and the coefficient of correlation were then used to evaluate the level of saturation: the slope decreases from one as saturation increases.

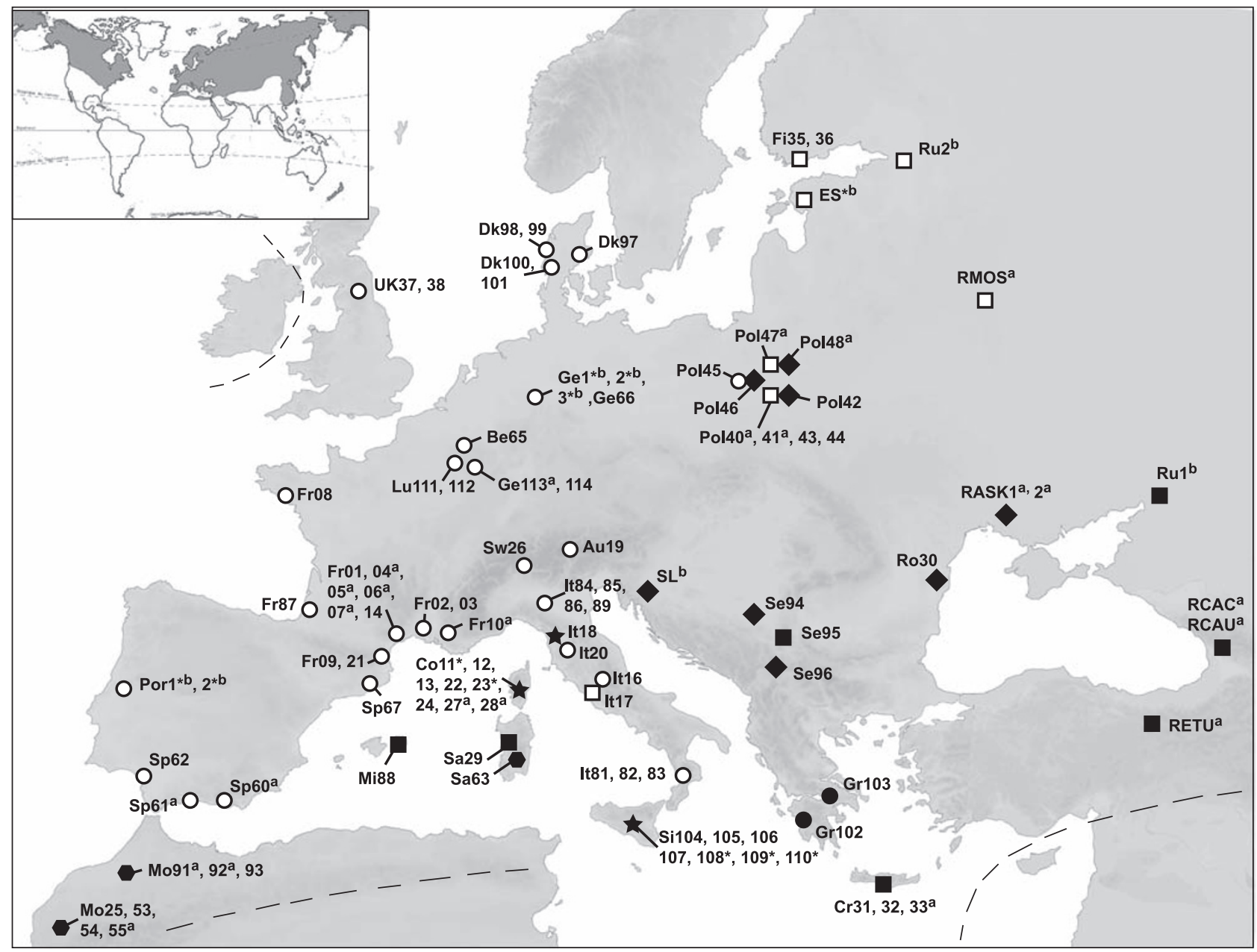

Figure 1 Sample localities of $M$. nivalis (see Table 1 for details). An asterisk $\left(^{*}\right.$ ) denotes samples for which precise locality is unknown Samples for which only the control region or the cytochrome $b$ is available are annotated ' $a$ ' and ' $b$ ', respectively. White and black symbols correspond to phylogenetic clades identified in Figure 2. The dotted line indicates the approximate distribution of $M$. nivalis and the inset map shows the entire species range. 
Table 1 Sampling location, sample symbols, tissue origin and sequence accession numbers

\begin{tabular}{|c|c|c|c|c|c|}
\hline \multicolumn{2}{|c|}{ Geographical origin of samples } & \multirow[t]{2}{*}{ Symbol } & \multirow[t]{2}{*}{ Donator or reference } & \multicolumn{2}{|c|}{ Accession number } \\
\hline Country & Locality & & & Control region & Cytochrome $b$ \\
\hline Austria & Grinzling & Au19 & Maria Grazia Filipucci & AM258893 & AM258847 \\
\hline Belgium & Blégny Trembleur & Be65 & Roland Libois & AM258921 ${ }^{\mathrm{a}}$ & AM258871 ${ }^{\text {a }}$ \\
\hline \multirow[t]{5}{*}{ Denmark } & Glesborg & Dk97 & Thomas Secher Jensen & AM258939 ${ }^{\mathrm{a}}$ & AM258887 \\
\hline & Lemvig & Dk98 & Thomas Secher Jensen & AM258940 a & AM258888 ${ }^{\mathrm{a}}$ \\
\hline & Tyvmose & Dk99 & Thomas Secher Jensen & AM258941 ${ }^{\mathrm{a}}$ & AM258889 ${ }^{\mathrm{a}}$ \\
\hline & Billund, Vandel Dam & Dk100 & Thomas Secher Jensen & AM258942 ${ }^{\mathrm{a}}$ & AM258890 \\
\hline & Olgod & Dk101 & Thomas Secher Jensen & AM258943 ${ }^{\mathrm{a}}$ & AM258891 ${ }^{\mathrm{a}}$ \\
\hline Estonia & Unknown & ES & $\begin{array}{l}\text { Saarma and Tumanov } \\
\text { (unpublished) }\end{array}$ & & AY188793 ${ }^{\mathrm{b}}$ \\
\hline \multirow[t]{2}{*}{ Finland } & Helsinki & Fi35 & Janne Sundell & AM258901 ${ }^{\mathrm{a}}$ & AM258859 ${ }^{\mathrm{a}}$ \\
\hline & Tampere & Fi36 & Janne Sundell & AM258902 ${ }^{\mathrm{a}}$ & AM258860 \\
\hline \multirow[t]{13}{*}{ France-Continent } & Aveyron, La Couvertoirade & Fr01 & Lebarbenchon et al. (2006) & AJ698489 & \\
\hline & $\begin{array}{l}\text { Bouches du Rhône, Saintes } \\
\text { Maries de la Mer }\end{array}$ & Fr02 & Lebarbenchon et al. (2006) & AJ698490 & \\
\hline & $\begin{array}{l}\text { Bouches du Rhône, } \\
\text { Montmajour }\end{array}$ & Fr03 & Lebarbenchon et al. (2006) & AJ698491 & AM258837 \\
\hline & Hérault, Murviel & Fr04 & Lebarbenchon et al. (2006) & AJ698492 & \\
\hline & Hérault, Mireval & Fr05 & Lebarbenchon et al. (2006) & AJ698493 & \\
\hline & Hérault, Le Caroux & Fr06 & Lebarbenchon et al. (2006) & AJ698494 & \\
\hline & Hérault, Mireval & Fr07 & Lebarbenchon et al. (2006) & AJ698495 & \\
\hline & Morbihan, Sarzeau & Fr08 & François Livet & $\mathrm{AM}_{258892^{\mathrm{a}}}$ & AM258838 \\
\hline & Pyrénées Orientales, Nohedes & Fr09 & Lebarbenchon et al. (2006) & AJ698496 & AM258839 ${ }^{\mathrm{a}}$ \\
\hline & Vaucluse, Vaugines & Fr10 & Lebarbenchon et al. (2006) & AJ698497 & \\
\hline & Aveyron, St Martin du Larzac & Fr14 & Lebarbenchon et al. (2006) & AJ698501 & AM258843 ${ }^{\mathrm{a}}$ \\
\hline & Pyrénées Orientales, Banyuls & Fr21 & Lebarbenchon et al. (2006) & AJ698502 & AM258849 ${ }^{\mathrm{a}}$ \\
\hline & Landes, Mont de Marsan & Fr87 & Elodie Magnanou & AM258930 & AM258880 \\
\hline \multirow[t]{8}{*}{ France-Corsica } & Unknown & Co11 & Lebarbenchon et al. (2006) & AJ698498 & AM258840 \\
\hline & Haute Corse, Querciolo & Co12 & Lebarbenchon et al. (2006) & AJ698499 & AM258841 ${ }^{\mathrm{a}}$ \\
\hline & Haute Corse, Linguezzata & Co13 & Lebarbenchon et al., 2006) & AJ698500 & AM258842 ${ }^{\mathrm{a}}$ \\
\hline & Corse du Sud, Portovecchio & Co22 & Lebarbenchon et al. (2006) & AJ698503 & AM258850 \\
\hline & Unknown & $\mathrm{Co} 23$ & Lebarbenchon et al. (2006) & AJ698504 & AM258851 ${ }^{\mathrm{a}}$ \\
\hline & Haute Corse, Muro & $\mathrm{Co} 24$ & Lebarbenchon et al. (2006) & AJ698505 & AM258852 ${ }^{\mathrm{a}}$ \\
\hline & Corse du sud, Bonifacio & Co27 & Lebarbenchon et al. (2006) & AJ698506 & \\
\hline & Haute Corse, Lucciana & $\mathrm{Co} 28$ & Lebarbenchon et al. (2006) & AJ698507 & \\
\hline \multirow[t]{2}{*}{ Georgia } & Tbilisi District & RCAC & Kurose et al. (2005) & AB049770 & \\
\hline & Lagodehi & RCAU & Kurose et al. (2005) & АB049764 & \\
\hline \multirow[t]{6}{*}{ Germany } & Bielefeld & Ge66 & Rainer Hutterer & AM258922 ${ }^{\mathrm{a}}$ & AM258872 \\
\hline & Konz & Ge113 & Bettina Schmitt & AM932880 a & \\
\hline & Konz & Ge114 & Bettina Schmitt & AM932881 ${ }^{\mathrm{a}}$ & AM932885 \\
\hline & Unknown & Ge1 & Hosoda et al. (2000) & & AB051264 \\
\hline & Unknown & $\mathrm{Ge} 2$ & Hosoda et al. (2000) & & $\mathrm{AB} 051265^{\mathrm{b}}$ \\
\hline & Unknown & Ge3 & Hosoda et al. (2000) & & AB051266 ${ }^{\mathrm{b}}$ \\
\hline \multirow[t]{2}{*}{ Greece-Continent } & Filiatra-Mesinia & Gr102 & Petros Platis & AM749057 & AM749048 \\
\hline & Vravrova-Athènes & Gr103 & Michel Thévenot & AM749058 & AM749049 \\
\hline \multirow[t]{3}{*}{ Greece-Crete } & Nida Platau & Cr31 & Petros Lymberakis & AM258898 & AM258857 \\
\hline & Karteros Iraklion & Cr32 & Petros Lymberakis & AM258899 ${ }^{\mathrm{a}}$ & AM258858 ${ }^{\mathrm{a}}$ \\
\hline & Vrises Hanion & Cr33 & Petros Lymberakis & AM258900 & \\
\hline \multirow[t]{11}{*}{ Italy-Continent } & Montelibretti & It16 & Lebarbenchon et al. (2006) & AJ849682 & $\mathrm{AM}^{258844^{\mathrm{a}}}$ \\
\hline & San Polo Dei Cavaliere & It17 & Lebarbenchon et al. (2006) & AJ849683 & AM258845 \\
\hline & Toscana, Pratolino & It18 & Lebarbenchon et al. (2006) & AJ849684 & AM258846 ${ }^{\mathrm{a}}$ \\
\hline & Toscana & It20 & Lebarbenchon et al. (2006) & AJ849685 & AM258848 \\
\hline & Cosenza, Valle Capra & It81 & Licia Colli & AM258924 ${ }^{\mathrm{a}}$ & AM258874 ${ }^{\mathrm{a}}$ \\
\hline & Cosenza, Rende & It82 & Licia Colli & AM258925 a & $\mathrm{AM} 258875^{\mathrm{a}}$ \\
\hline & Cosenza, Cellara & It83 & Licia Colli & AM258926 ${ }^{\mathrm{a}}$ & AM258876 ${ }^{\mathrm{a}}$ \\
\hline & Parma, Collecchio & It84 & Licia Colli & AM258927 & AM258877 \\
\hline & Parma, Sala Baganza & It85 & Licia Colli & AM258928 & AM258878 \\
\hline & Parma, Fugazzolo & It86 & Licia Colli & AM258929 & AM258879 ${ }^{\mathrm{a}}$ \\
\hline & Plain of Po & It89 & Françoise Poitevin & AM258932 ${ }^{\mathrm{a}}$ & AM$^{2} 58882^{\mathrm{a}}$ \\
\hline Italy-Sardinia & West center & Sa29 & Gilles Cheylan & AM258896 & AM258855 \\
\hline & Sassari & Sa63 & José Cabot & AM258920 & AM258870 \\
\hline Italy-Sicily & Castellammare del & Si104 & Mario Lovalvo & AM749059 & AM749050 \\
\hline & Vicari-Palermo & Si105 & Mario Lovalvo & AM749060 & AM749051 ${ }^{\mathrm{a}}$ \\
\hline & St Stefano-Palermo & Si106 & Mario Lovalvo & AM749061 ${ }^{\mathrm{a}}$ & $\mathrm{AM} 79052^{\mathrm{a}}$ \\
\hline & Sicile orientale & Si107 & Mario Lovalvo & AM749062 $^{\mathrm{a}}$ & AM749053 $^{\text {a }}$ \\
\hline & Unknown & Si108 & Mario Lovalvo & AM749063 & AM749054 ${ }^{\mathrm{a}}$ \\
\hline & Unknown & Si109 & Mario Lovalvo & AM749064 & AM749055 \\
\hline & Unknown & Si110 & Mario Lovalvo & AM749065 & AM749056 ${ }^{\mathrm{a}}$ \\
\hline
\end{tabular}


Table 1 Continued

\begin{tabular}{|c|c|c|c|c|c|}
\hline \multicolumn{2}{|c|}{ Geographical origin of samples } & \multirow[t]{2}{*}{ Symbol } & \multirow[t]{2}{*}{ Donator or reference } & \multicolumn{2}{|c|}{ Accession number } \\
\hline Country & Locality & & & Control region & Cytochrome b \\
\hline \multirow[t]{2}{*}{ Luxembourg } & Berbourg & Lu111 & Bettina Schmitt & AM932878 & AM932883 \\
\hline & Berbourg & Lu112 & Bettina Schmitt & AM932879 & AM932884 \\
\hline \multirow[t]{7}{*}{ Morocco } & Marrakech region & Mo25 & Fabrice Cuzin & AM258894 & $\mathrm{AM} 258853^{\mathrm{a}}$ \\
\hline & Marrakech region & Mo53 & Fabrice Cuzin & $\mathrm{AM}_{258914^{\mathrm{a}}}$ & AM258867 \\
\hline & Marrakech region & Mo54 & Fabrice Cuzin & AM258915 & AM258868 \\
\hline & Marrakech region & Mo55 & Fabrice Cuzin & AM258916 & \\
\hline & Casablanca region & Mo91 & Michel Thévenot & AM258933 ${ }^{\mathrm{a}}$ & \\
\hline & Casablanca region & Mo92 & Michel Thévenot & AM258934 ${ }^{\mathrm{a}}$ & \\
\hline & Casablanca region & Mo93 & Michel Thévenot & AM258935 & AM258883 ${ }^{\mathrm{a}}$ \\
\hline \multirow[t]{9}{*}{ Poland } & Bialowieza & Po40 & Karol Zub & AM258905 & \\
\hline & Bialowieza & Po41 & Karol Zub & AM258906 ${ }^{\mathrm{a}}$ & \\
\hline & Bialowieza & Po42 & Karol Zub & $\mathrm{AM} 258907^{\mathrm{a}}$ & AM258863 ${ }^{\mathrm{a}}$ \\
\hline & Bialowieza & Po43 & Karol Zub & AM258908 & AM258864 \\
\hline & Bialowieza & Po44 & Karol Zub & AM258909 ${ }^{\mathrm{a}}$ & AM258865 \\
\hline & Kampinos & Po45 & Karol Zub & AM258910 & AM932882 \\
\hline & Kampinos & Po46 & Karol Zub & AM258911 ${ }^{\mathrm{a}}$ & $\mathrm{AM} 258866^{\mathrm{a}}$ \\
\hline & Biebrza & Po47 & Karol Zub & AM258912 & \\
\hline & Biebrza & Po48 & Karol Zub & AM258913 ${ }^{\mathrm{a}}$ & \\
\hline \multirow[t]{2}{*}{ Portugal } & Unknown & Port1 & Fernandez et al. (2007) & & EF689080 \\
\hline & Unknown & Port2 & Fernandez et al. (2007) & & EF689081 \\
\hline Romania & Delta's Danube & Ro30 & Johan Michaux & AM258897 & $\mathrm{AM} 258856^{\mathrm{a}}$ \\
\hline \multirow[t]{3}{*}{ Russia } & Rostov & RU1 & Hosoda et al. (2000) & & $\mathrm{AB} 051267^{\mathrm{b}}$ \\
\hline & Leningrad & RU2 & $\begin{array}{l}\text { Saarma and Tumanov } \\
\text { (unpublished) }\end{array}$ & & AY $188794^{b}$ \\
\hline & Moscow Province & RMOS1 & Kurose et al. (2005) & AB049766 & \\
\hline \multirow[t]{3}{*}{ Serbia } & Dobanovci & Se94 & Dusko Cirovic & AM258936 ${ }^{\mathrm{a}}$ & AM258884 ${ }^{\mathrm{a}}$ \\
\hline & Backo Dobro Polje & Se95 & Dusko Cirovic & AM258937 & AM258885 \\
\hline & Svilajnac, Sedlare & Se96 & Dusko Cirovic & AM258938 & AM258886 \\
\hline Slovenia & East Slovenia & SL & Davison et al. (1999) & & AF068545 \\
\hline \multirow[t]{4}{*}{ Spain-Continent } & Granada & Sp60 & José Cabot & AM258917 & \\
\hline & Malaga & Sp61 & José Cabot & AM258918 & \\
\hline & Huelva & Sp62 & José Cabot & AM258919 & AM258869 \\
\hline & $\begin{array}{l}\text { Barcelona, Natural } \\
\text { Park of Montseny }\end{array}$ & Sp67 & Alexis Ribas & AM258923 & $\mathrm{AM} 258873^{\mathrm{a}}$ \\
\hline Spain-Baleares & Minorca & Mi88 & Evarist Coll & AM258931 ${ }^{\mathrm{a}}$ & AM258881 ${ }^{\mathrm{a}}$ \\
\hline Switzerland & Tessin, Cadagno lake & Sw26 & François Catzeflis & AM258895 & $\mathrm{AM} 258854^{\mathrm{a}}$ \\
\hline Turkey & Kars Province & RETU & Kurose et al. (2005) & AB049776 & \\
\hline \multirow[t]{2}{*}{ Ukraine } & Askania-Nova & RASK1 & Kurose et al. (2005) & AB049765 & \\
\hline & Askania-Nova & RASK2 & Kurose et al. (2005) & AB049768 & \\
\hline \multirow[t]{2}{*}{ United Kingdom } & Kielder & UK37 & Xavier Lambin & AM258903 ${ }^{\mathrm{a}}$ & AM258861 ${ }^{\mathrm{a}}$ \\
\hline & Kielder & UK38 & Xavier Lambin & $\mathrm{AM} 258904^{\mathrm{a}}$ & AM258862 \\
\hline \multicolumn{6}{|l|}{ OUTGROUP } \\
\hline \multicolumn{2}{|l|}{ Mustela putorius } & & Kurose et al. (1999); Kurose et al. (2000) & AB010379 & AB026107 \\
\hline \multicolumn{2}{|l|}{ Mustela eversmanni } & & Michaux et al. (2004); Kurose et al. (2000) & AJ548476 & AB026102 \\
\hline \multicolumn{2}{|l|}{ Mustela lutreola } & & Michaux et al. (2005); Kurose et al. (2000) & AJ548803 & AB026105 \\
\hline \multicolumn{2}{|l|}{ Mustela itatsi } & & Kurose et al. (2005); Kurose et al. (2000) & AB007327 & AB026104 \\
\hline \multicolumn{2}{|l|}{ Mustela erminea 1} & & Kurose et al. (1999); Kurose et al. (2000) & AB006729 & AB026101 \\
\hline \multicolumn{2}{|l|}{ Mustela erminea 2} & & Kurose et al. (1999); Fleming and Cook (2002) & AB006731 & AF271061 \\
\hline
\end{tabular}

${ }^{\mathrm{a}}$ Submitted for this article.

${ }^{\mathrm{b}}$ Sequences incomplete for the cytochrome $b$ (about $350 \mathrm{bp}$ ).

Phylogenetic trees were reconstructed in maximum parsimony with PAUP (version 4.0b10; Swofford, 2002), in maximum likelihood using PHYML and with the Bayesian inference using MRBAYES (version 3.1.2; Ronquist and Huelsenbeck, 2003). The search for the maximum parsimony trees was performed with the option stepwise addition with simple addition sequence and stability of nodes was assessed with 1000 boostrap replications. For the two probabilistic methods, the optimal model of sequence evolution was determined with MODELGENERATOR (version 0.82; Keane et al., 2006), using the majority model indicated by the four tests (LRT, AIC1, AIC2 and BIC). As PHYML does not allow for data partition, the model of sequence evolution was inferred by MODELGENERATOR on whole genes (separately or in combination) and stability of nodes was tested with 1000 bootstrap replications. With MRBAYES, a mixed-model analysis was performed on partitioned genes using different models (selected by MODELGENERATOR) and parameters for four partitions (ctr and each codon position for the $c y t b$ ). MRBAYES was run using four chains of four millions of generations sampled for each 100 generations, with the first 10000 trees discarded as burn-in after checking stationary of loglikelihood values.

\section{Dating analysis}

Divergence dates were estimated by Bayesian coalescent analysis with the program BEAST (version 1.4.6; 
Drummond and Rambaut, 2007) using the complete combined dataset (68 weasels sequenced for both genes and 6 outgroups). We used the HKY model of nucleotide substitution with a proportion of invariable site (I) and a Gamma distribution (G). Three coalescent priors (constant size, exponential growth and expansion growth) as well as three molecular clock models (strict, relaxed exponential and lognormal) were evaluated and tested using the Bayes factor (BF) as implemented in the program TRACER (version 1.4; Rambaut and Drummond, 2007). BF significance was determined from the values of $2 \mathrm{LnBF}$ as described in Brandley et al. (2005). Chains were run twice independently for 30-million generations each, sampled every 1000 iterations with the first $10 \%$ of trees discarded as burn-in. The program TRACER was used to check for convergence of MCMC chains to stationarity (effective sample size >600). The results of the two independent analyses were combined using the program Logcombiner to calculate the time of divergence from the most recent common ancestor (TMRCA) and 95\% highest posterior density (HPD) intervals.

Molecular dating was derived using as calibration point the age of the first occurrence of $M$. nivalis, which is dated at 300 kiloyear (kyr) in North America and $100 \mathrm{kyr}$ in Eurasia (The PaleoBiology Database, http://paleodb. org). A lognormal distribution suitable for modelling fossil data (Ho, 2007) was used as prior with parameter values of $100 \mathrm{kyr}$ as the minimum age (lower bound parameter), $300 \mathrm{kyr}$ as the mean and the standard deviation of the distribution was chosen to 2 , so that 95\% of the HPD for the time of divergence of the $M$. nivalis clade lies in the interval 100-500 kyr (late-middle Pleistocene; Sheffield and King, 1994).

The expansion time was estimated from the mismatch distribution as $t=\tau /(2 \mu)$, where $t$ is the time since expansion in generation, $\tau$ is the mode of the mismatch distribution and $\mu$ is the mutation rate per nucleotide multiplied by the sequence length (Rogers, 1995). We assumed one generation per year, and for the substitution rate, we used the mean and 95\% HPD estimations obtained from BEAST analyses to calculate the expansion time with $95 \%$ confidence interval (CI).

\section{Results}

\section{Phylogenetic analyses}

Ninety-four ctr weasel sequences have been analysed for 550 nucleotides (including 7 indels), which yielded 49 haplotypes showing $43(7.8 \%)$ variable and $33(6 \%)$ informative sites. Intraspecific sequence variation between haplotypes varies from 0.18 to $3.85 \%$. The slope of the regression and correlation coefficient of the saturation analysis were 0.77 and 0.83 , respectively. These values indicate that the ctr was little affected by saturation, although values were slightly lower than for the cytb (see below). The complete ctr dataset includes 100 animals (94 weasels and 6 outgroups) and $\mathrm{HKY}+\mathrm{I}+\mathrm{G}$ was selected as the best-fitting model of sequence evolution. On the whole, the $c t r$ did not reveal strong phylogeographic structure with the exception of a clade including samples from western Europe (clade I in Supplementary Appendix S1a).
Thirty-six different haplotypes have been identified for 70 weasel complete cytb sequences (Table 1), which showed $82(7.2 \%)$ variable sites among which $42(3.7 \%)$ were informative. Intraspecific sequence variation between haplotypes varied from 0.088 to $2.28 \%$. The slope of the regression and correlation coefficient of the saturation analysis was 0.85 and 0.98 , respectively, indicating that the $c y t b$ was not affected by saturation.

Phylogenetic analyses were performed on $83 c y t b$ when partial sequences and outgroups were included. The best model of sequence evolution was TrNef $+\mathrm{I}$, $\mathrm{HKY}$ and $\operatorname{TrN}$, for the first, second and third position, respectively, whereas the $\mathrm{HKY}+\mathrm{G}$ model was selected for the whole cytb. In Bayesian analysis, we used the GTR model instead of TrNef and $\operatorname{TrN}$, which are not available in MRBAYES. The resulting trees revealed two moderately supported clades (I and II in Appendix S1b). Two groups can be identified in clade I. Subclade Ia contained all weasels from the western part of Europe from Spain to Finland among which a uniform phylogeographic pattern was observed. Subclade Ib was weakly supported and included seven samples (two individuals from Poland, two from Finland and one from central Italy, Estonia and Russia each). In contrast, group II was clearly structured in five rather well-supported subclades including individuals from (i) Greece; (ii) Crete, Minorca, Sardinia and Serbia; (iii) Poland, Romania, Slovenia and Serbia; (iv) Corsica, north Italy and Sicily and (v) Morocco and Sardinia.

The combined analysis included 74 samples (68 weasels and 6 outgroups) for 1690 nucleotides, and $\mathrm{HKY}+\mathrm{I}+\mathrm{G}$ was selected as the best model of sequence evolution. The phylogenetic tree (Figure 2a) strengthened the arrangement in two main clades (I and II) observed with the $c y t b$ alone (Appendix S1b), and the same five subclades were strongly supported in group II. This indicates that while less information was brought by the $c t r$, there was little conflict with the structure given by the $c y t b$. The phylogenetic analysis of the westernPalaearctic weasels thus reveals an opposition between the clade I unstructured and including only one strong group (subclade Ia) and the clade II split into five wellsupported subgroups.

The minimum spanning network (Figure 2b) performed on the whole combined dataset (68 weasels) showed the same general pattern with clades I and II separated by 18 mutational steps. The absence of structure inside subclade Ia was also apparent, along with a star-like topology indicative of a demographic expansion (stronger evidence with $c y t b$ alone, data not shown).

\section{Genetic structure}

The mean divergence, estimated from combined markers by the uncorrected $p$ distance (percentage of divergence), was low within each clade $(0.49 \pm 0.3 \%$ for clade I and $0.6 \pm 0.31 \%$ for clade II), whereas the differentiation between the two groups was $<2 \%(1.8 \pm 0.18 \%)$. These estimates are not uncommon for carnivores and, for example, are in agreement with the mean percentage divergence observed for stoat (M. erminea; Fleming and Cook, 2002; Martinkova et al., 2007). 
Genetic diversity was calculated for phylogenetic (Figure 2a) and geographic (each Mediterranean island, Morocco and eastern-continental individuals) groups. Haplotype diversity was high $(h>0.80)$ for all clades, whereas nucleotide diversity was heterogeneous between different groups (Table 2), with lower values recorded for groups including insular samples. This analysis, combined with the average number of

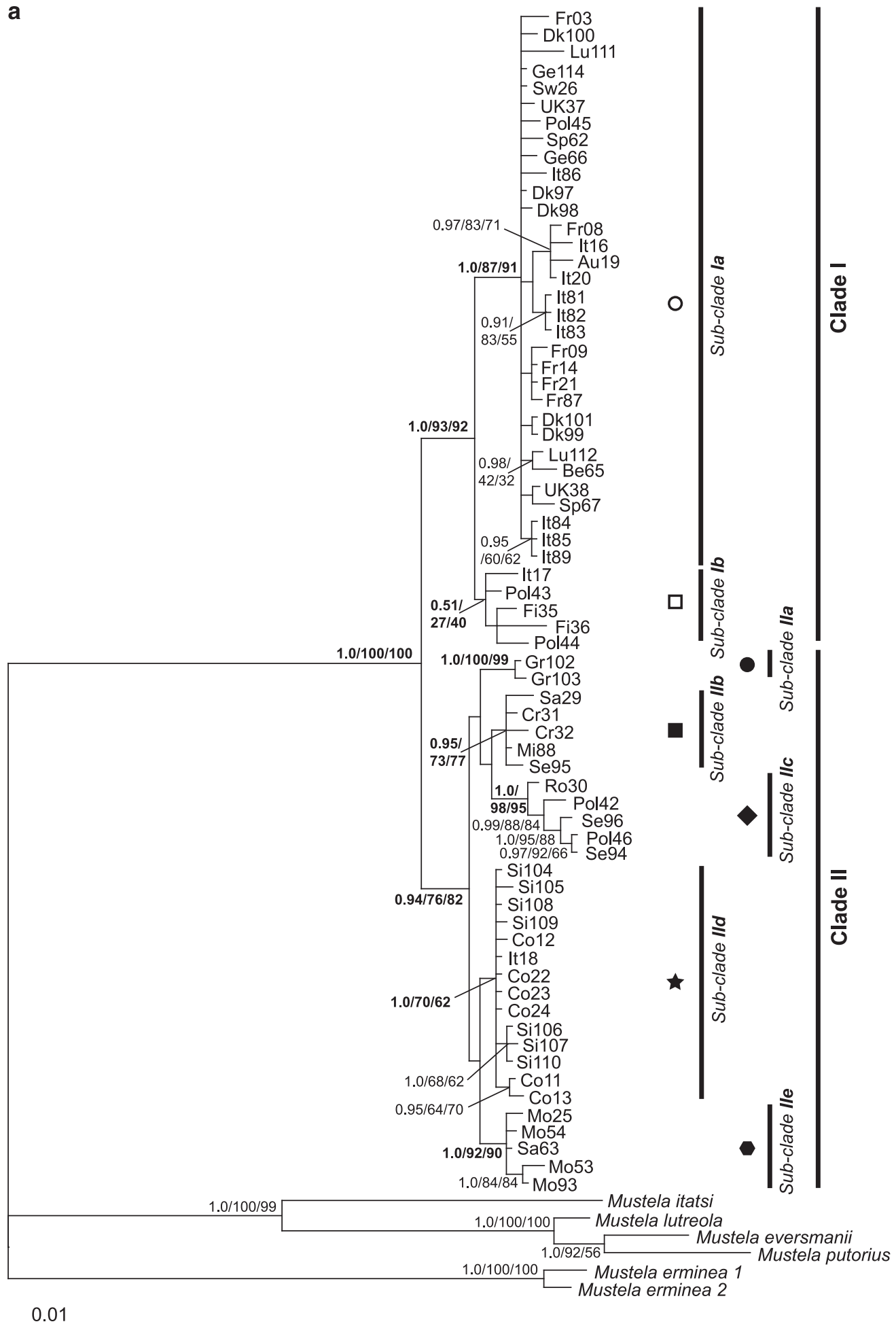

Figure 2 (a) Bayesian phylogram derived from the combined control region and cytochrome $b$ for 68 M. nivalis (see Table 1 for sample names). Bayesian posterior probabilities and bootstrap proportions in maximum likelihood and maximum parsimony are shown at nodes from left to right, respectively. With the exception of clade Ib, only nodes supported by at least $90 \%$ support for at least one method are indicated. Supports for main clades and subclades are indicated in bold. (b) Minimum spanning network for the same 68 sequences. Black dots represent missing haplotypes. Unless specified, the number of substitution between haplotypes is one. 


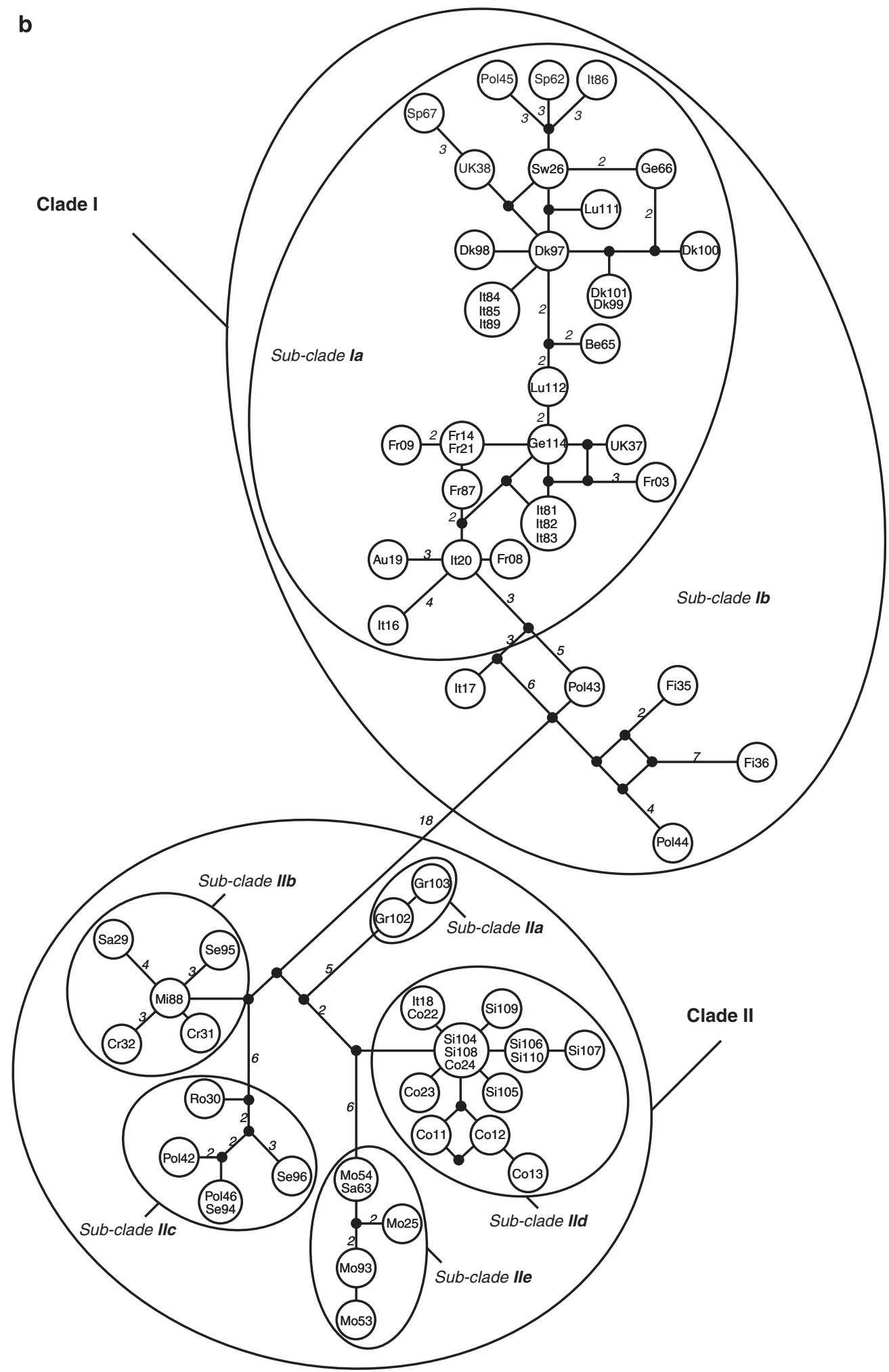

Figure 2 Continued.

nucleotide differences ( $k$ in Table 2), highlights that subclades IIa and IId, and especially samples from Corsica and Sicily, present the lowest genetic diversities.

Three statistical tests (Fu's Fs, Tajima's $D$ statistic, $R_{2}$ test; Table 2) as well as mismatch distributions were performed to infer demographic histories (stability or expansion of population). The Tajima's $D$ statistic was the most restrictive test with 10 out of 13 groups tested showing a probability above 0.05 (thus rejecting the hypothesis of expansion), whereas the two other tests reject this hypothesis $(P>0.05)$ for seven groups. In contrast, mismatch distributions accepted the hypothesis 
Table 2 Genetic polymorphism and neutrality tests

\begin{tabular}{|c|c|c|c|c|c|c|c|c|c|}
\hline Groups & $\mathrm{n}$ & $\mathrm{n}_{H}$ & $\mathrm{~h}($ s.d.) & $\pi(s . d)$. & $\mathrm{k}$ & Fs & $\mathrm{D}$ & $\mathrm{R}_{2}$ & $\tau$ \\
\hline \multicolumn{10}{|l|}{ Phylogroups ${ }^{\mathrm{a}}$} \\
\hline All clades & 68 & 53 & $0.99(<0.001)$ & $0.0092(<0.001)$ & 14.96 & $-27.87^{* * *}$ & -0.99 & 0.07 & 31.93 \\
\hline Clade I & 37 & 31 & $0.99(<0.001)$ & $0.0043(<0.001)$ & 7.03 & $-22.64^{* * *}$ & $-1.73^{*}$ & $0.06^{* *}$ & 3.55 \\
\hline Subclade Ia & 32 & 26 & $0.98(<0.001)$ & $0.0033(<0.001)$ & 5.49 & $-19.19^{* * *}$ & -1.39 & $0.07^{*}$ & 5.08 \\
\hline Subclade Ib & 5 & 5 & $1(0.13)$ & $0.0058(<0.005)$ & 9.8 & -0.37 & -0.83 & $0.09 *$ & 10.8 \\
\hline Clade II & 31 & 22 & $0.96(<0.001)$ & $0.0049(<0.001)$ & 8.09 & $-7.62^{*}$ & -1.41 & $0.07^{*}$ & 13.23 \\
\hline Subclade IIa & 2 & 2 & $1(0.50)$ & $0.0006(<0.001)$ & 1.00 & NA & NA & NA & NA \\
\hline Subclade IIb & 5 & 5 & $1(0.13)$ & $0.0024(<0.001)$ & 4.00 & -1.72 & $-1.19^{*}$ & $0.14^{*}$ & 4.78 \\
\hline Subclade IIc & 5 & 4 & $0.90(0.16)$ & $0.0027(<0.001)$ & 4.60 & 0.36 & -0.30 & 0.16 & $6.65^{* * *}$ \\
\hline Subclade IId & 14 & 8 & $0.82(0.09$ & $0.0009(<0.001)$ & 1.48 & $-4.54^{* * *}$ & $-1.55^{*}$ & $0.09^{* *}$ & 3.02 \\
\hline Subclade IIe & 5 & 4 & $0.90(0.16)$ & $0.0019(<0.001)$ & 3.20 & -0.23 & -0.33 & 0.20 & 2.15 \\
\hline \multicolumn{10}{|l|}{ Geographic groups } \\
\hline Eastern-continental & 9 & 8 & $0.97(0.06)$ & $0.0064(<0.001)$ & 10.80 & -0.88 & 0.06 & 0.15 & 17.74 \\
\hline Sicily & 7 & 5 & $0.91(0.10)$ & $0.0010(<0.001)$ & 1.71 & $-1.89 *$ & -0.79 & 0.16 & NA \\
\hline Corsica & 6 & 4 & $0.80(0.17)$ & $0.0007(<0.001)$ & 1.20 & -1.45 & -0.45 & 0.18 & 3.66 \\
\hline Morocco & 4 & 4 & $1(0.18)$ & $0.0026(<0.001)$ & 4.33 & -0.72 & -0.07 & 0.16 & 6.02 \\
\hline
\end{tabular}

Abbreviations: $D$, Tajima's $D$; Fs, Fu's Fs; $h$, haplotype diversity; $k$, the average number of nucleotide differences; $n$, number of sequences; NA, not available (low sample size or computational limits of the program); $n_{\mathrm{H}}$, number of haplotypes; $R_{2}, R_{2}$ test; s.d., standard deviation; $\tau$, time since expansion (in units of mutational time) estimated from mismatch distributions; $\pi$, nucleotide diversity.

Probability of the test, ${ }^{* * *}<0.001,{ }^{* *}<0.01,{ }^{*}<0.05$, no star: non-significant.

a Defined from the phylogenetic tree obtained on combined sequences (1690 bp) (Figure 2a).

of recent population growth for all populations except one (subclade IIc). Discrepancies between tests can be explained by differences in their statistical power or in the sequence information used (Ramos-Onsins and Rozas, 2002). Therefore, we considered a population in expansion only if results from at least three tests were significant. According to these constraints, five phylogenetic clades (clade I, subclade Ia, clades II, IIb and IId) were considered as expanding groups.

\section{Molecular dating}

The difference in likelihood between the strict $(-5038.26)$, relaxed lognormal $(-5025.55)$ and relaxed exponential $(-5015.01)$ molecular clock reveals that the exponential model was significantly more adapted to our dataset $(2 \mathrm{LnBF}>10)$. Similarly, the test of three demography priors indicated that the constant size $(-5015.28)$ hypothesis cannot be rejected $(2 \mathrm{LnBF}<2)$ as compared with the exponential $(-5014.84)$ and expansion $(-5015.99)$ growth coalescents. Consequently, the relaxed exponential clock and constant population size prior were used to estimate the age of the TMRCA for different phylogenetic and geographic groups (Table 3; and Figure 4).

Three periods of diversification can be recognized for weasels: (i) $116 \mathrm{kyr}$ for the TMRCA of the whole westernPalaearctic lineage (clade I), (ii) 50-60 kyr for the timing of the eastern-Palaearctic continental and western (subclade Ia) populations and (iii) $18-28 \mathrm{kyr}$ for the TMRCA of the Moroccan, Sicilian and Corsican populations. For the outgroups, the split between M. lutreola and $M$. eversmanni + M. putorius was $133 \mathrm{kyr}$, which is the same timing as the divergence of clade I. The divergence of $M$. itatsi from other mustelids was dated at $389 \mathrm{kyr}$.

The mean mutation rate was evaluated at 112 substitutions per site per kyr (95\% HPD: 8.9-233 kyr) by BEAST analyses. This value and 95\% HPD interval were used to infer time of expansion from mismatch
Table 3 Estimated time (in kiloyears) to the most recent common ancestor (TMRCA) and expansion time for different groups of interest using a Bayesian coalescent analysis (BEAST program) and the mismatch distributions

\begin{tabular}{lccccc}
\hline Group & \multicolumn{2}{c}{ BEAST } & & \multicolumn{2}{c}{ Mismatch distribution } \\
\cline { 2 - 3 } \cline { 6 - 6 } & TMRCA & $95 \%$ HPD & & Expansion time & $95 \%$ CI \\
\hline Clade I & 116 & $126-287$ & & 9 & $5-117$ \\
Subclade Ia & 62 & $7-158$ & & 13 & $7-167$ \\
Corsica & 18 & $1.2-48$ & & 10 & $5-120$ \\
Sicily & 18 & $1.4-49$ & & NA & NA \\
Morocco & 28 & $1.3-78$ & & 16 & $8-198$ \\
Clade II-continent & 50 & $5-130$ & & 35 & $23-583$ \\
All weasels & 220 & $100-520$ & & 84 & $41-1049$
\end{tabular}

Abbreviations: $\mathrm{CI}$, confidence interval; HPD, highest posterior density; NA, not available; TMRCA, time of divergence from the most recent common ancestor.

analysis for different clades (Table 3). Values were rather different, notably for clades I and Ia.

\section{Discussion}

\section{Differentiation in northern refugia?}

On the basis of extensive sampling in the westernPalaearctic region and the use of two mitochondrial genes $(1690 \mathrm{bp})$, we have shown for the first time a clear phylogeographic pattern for the weasel, revealing a split into two major groups (clades I and II in Figure 2). Clade I includes all individuals sampled in the westernPalaearctic region, from Spain to Finland and including the United Kingdom (white symbols in Figure 1), and clade II encompasses samples from eastern Europe to the 

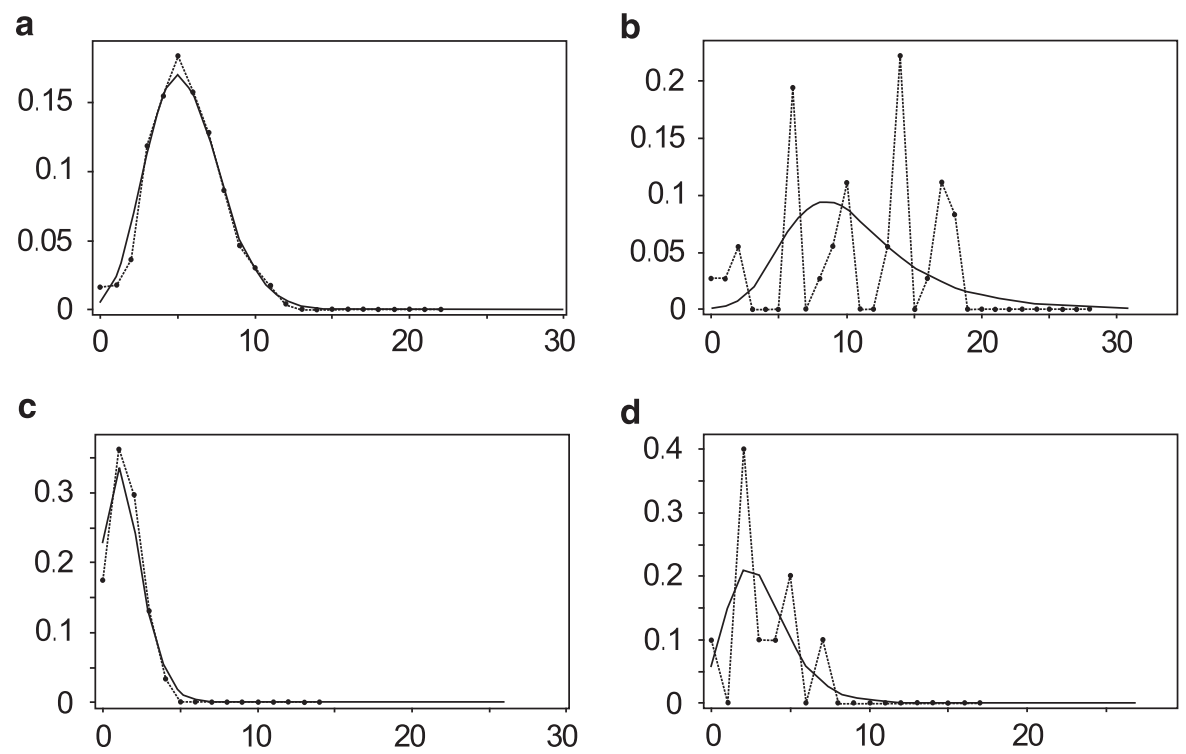

Figure 3 Observed (dot line) and expected (solid line) mismatch distributions under a population growth-decline model for different $M$. nivalis clades (see Figure 2a) of interest: (a) clade Ia, (b) clade II east-continental samples (after exclusion of insular and Moroccan samples), (c) clade IId and (d) clade IIe.

Black Sea as well as all Moroccan and insular weasels (black symbols in Figure 1).

Group I contained a strongly supported clade (Ia) including all western-European weasels (except It18) and a weakly supported clade $(\mathrm{Ib})$ including five individuals located at the edge of the distribution area of clade I (Figure 1). As these haplotypes are the oldest among clade I and are mostly located in Finland and Poland, it can be inferred that clade I probably originated in northeastern Europe. Several explanations can be put forward to account for these individuals. First, they could carry ancestral polymorphisms because of incomplete lineage sorting (Maddison and Knowles, 2006). There is, however, little support for this hypothesis because samples are geographically localized, which is not consistent with the retention of ancestral variation. Second, these individuals could result from admixture with another genetic group not identified in our study because it is located farther east. To check for the existence of another group in the eastern part of Eurasia, we added all complete weasel $c y t b$ sequences available in European Molecular Biology Laboratory. Only two sequences from Japan and one from Taiwan were found. The resulting tree (not shown) indicates that these sequences also clustered at the base of clade I, thus suggesting that clade I might effectively include other lineages expanding to the eastern part of the Palaearctic region. Third, a replacement event can be proposed by which these intermediate samples would represent a residual clade I (formerly covering the whole westernPalaearctic region) displaced by range expansion of subclade Ia. This hypothesis is supported by the observation that subclade Ia is nestled within clade I, and, therefore, group Ia likely originated from group I. Such a replacement process has been used to explain the different lineages observed in Scotland and England/ Wales for the water vole (Arvicola terrestris, Piertney et al., 2005) or in Ireland and Britain for the stoat (Martinkova et al. 2007).
The subclade Ia showed no phylogeographic structure and has characteristics consistent with sudden expansion: a bell-shaped curve of the mismatch distribution (Figure 3a), rejection of the hypothesis of neutrality (Table 2) and a star-like network (particularly for the $c y t b)$. These features suggest some contraction of population size in the past, likely during the last glacial cycles as indicated by the time of expansion ( $13 \mathrm{kyr}$; $95 \%$ CI: 7-167 kyr). For this clade, our data do not support the hypothesis of refugia located in the Mediterranean peninsulas because observation of the network (Figure $2 b$ ) reveals that individuals from Spain or Italy are mostly located at the periphery of the network, whereas central nodes are occupied by individuals from Denmark (Dk97), Switzerland (Sw26) or Germany (Ge114). These results thus lead to the assumption that clade Ia originated from clade I in northeastern Europe and then spread to southwestern regions. The interpretation of northern-European refugium would also be consistent with the ecology of weasels, which are presently found from the southern and northern extremes of Europe and in mountains up to $3000 \mathrm{~m}$. These characteristics suggest that, as cold-tolerant animals, weasels would have been able to survive at different latitudes (to the boundary of the ice sheet) during successive glaciations. The presence of weasel subfossils recorded during the pleniglacial age $(15-75 \mathrm{kyr})$ of central Europe (Germany, Poland; Sommer and Benecke, 2004) is also consistent with this hypothesis. Of course, more samples from northern countries (Sweden, Norway) to the Extreme Orient would be needed to support this scenario.

Clade II showed a topology with five well-supported subgroups (Figure 2). When samples from clade II are restricted to continental individuals (nine weasels from Greece, Serbia, Romania, Italy, Poland), there is no indication of recent population growth: the mismatch distribution curve is multimodal (Figure $3 b$ ) and close to the rejection threshold ( $P=0.08$; see also subclade IIc). 
Moreover, the failure to reject the neutrality hypothesis (Table 2) rather suggests constant population size. In contrast to western-European weasels, easterncontinental populations seem to have been more stable during the ice ages and would not have undergone reduction in population size. Although based on a small sampling, our data do not support the hypothesis of a refugium located in the Balkan area. This pattern of more stable populations in the Balkans has already been described for the bi-coloured shrew (Crocidura leucodon; Dubey et al., 2007b) and the yellow-necked fieldmouse (Apodemus flavicollis; Michaux et al., 2005). This might be explained by milder climatic conditions prevailing in places farther from the ice sheet. A more comprehensive sampling from northern and middleeastern regions (Carpathian, Balkan, Black Sea until Caspian areas) would help to delineate the geographic distribution of clade II and to better identify refugia potentially located in more northern (Carpathian) or eastern (Caucasus) areas (see Jaarola and Searle, 2002; Brunhoff et al., 2003).

Molecular dating indicates that the divergence of subclade Ia and clade II (continental samples) occurred 62 and $50 \mathrm{kyr}$ ago, respectively (95\% HPD: 5-158 kyr; see Table 3; Figure 4). The proximity of these dates suggests that the two clades originated from the same event and fall during the last glacial period, namely the Würm glaciation (10-80 kyr). Thus, we can reasonably assume that the last glacial period was responsible for the emergence of these two distinct genetic groups, but with quite different consequences. Whereas the western-Palaearctic group has likely undergone all consequences of a distribution restricted to glacial refugia, the eastern-continental group does not express any characteristic of a refugium zone. The molecular dating obtained for the clade I (extended western Palaearctic) is dated approximately $116 \mathrm{kyr}$ ago $(95 \%$ CI: $126-287 \mathrm{kyr})$, which corresponds to the end of the Riss glaciation.

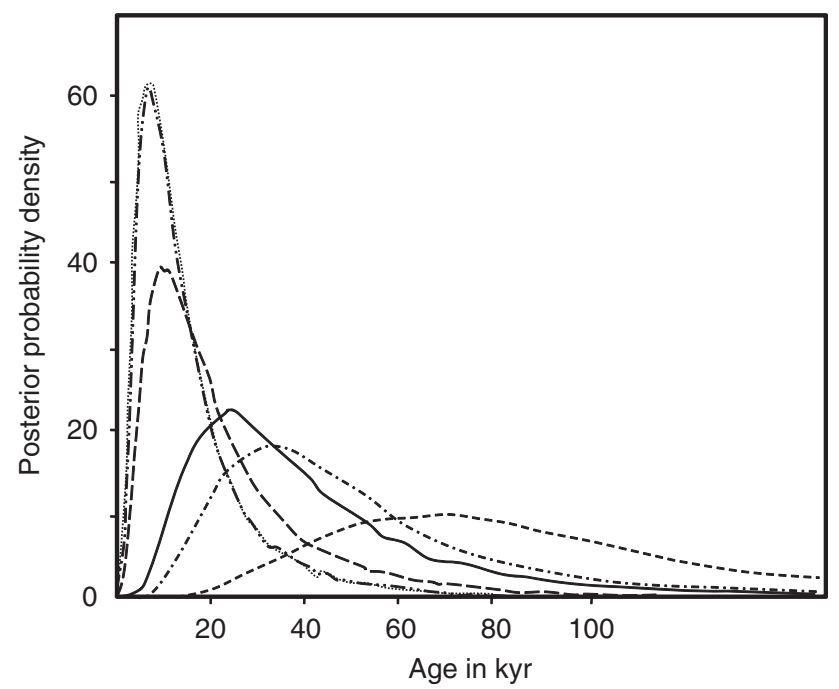

Figure 4 Bayesian posterior density plot showing the distribution of the age of the most recent common ancestor for clade I (--- ) , clade Ia (-) and Corsican (-..-), Sicilian (.....), Moroccan $\left(-\ldots \_\right)$and east-continental $(-\cdot-\cdot)$ populations of $M$. nivalis (see Table 3 for estimated ages).
Colonization of Mediterranean islands

The question of how (natural or introduced populations) and when (during the Pleistocene or at human scale) the current mammalian species colonized the different Mediterranean islands is still open to debate (Vigne, 1999; Lister, 2004; Marra, 2005). During the Holocene, the replacement of endemic mammalian species by a poorly diversified introduced fauna occurred on all of the larger Mediterranean islands (Blondel and Vigne, 1993). For $M$. nivalis, there is no clear explanation concerning the modality of island introduction. However, the lack of fossil records (Vigne and Alcover, 1985; Masseti, 1995; Vigne, 1999) suggests the absence of $M$. nivalis not only on most islands, but also in the western part of North Africa (Morocco, Algeria and Tunisia) during the Pleistocene and early Holocene ages. Hence, colonization through human intervention (voluntary or not) seems to be the prevailing hypothesis (Vigne, 1999; Bover and Alcover, 2008).

According to our results, it is noticeable that, with the exception of Crete, all Mediterranean islands do not belong to the same genetic group as the nearest continent. Corsica, Sardinia, Sicily and Minorca are included in the genetic clade II, whereas their corresponding closest mainland regions (France, Italy and Spain) are in the genetic group I (Figures 1 and 2). It can thus be inferred that islands have not been colonized from the nearest continent, as already shown from a smaller sampling (Lebarbenchon et al., 2006). Rather, the clustering of insular samples with weasels from Serbia, Greece and Romania suggests that islands were likely colonized by individuals originating from an easternEuropean group. Owing to this common origin, our genetic data argue in favour of a human introduction, which is also congruent with the early trade routes that have been established in eastern civilizations since the Bronze age (De Marinis and Masseti, 2003; Costa, 2004). Moreover, a common eastern origin through natural colonization across land masses seems to be unlikely because of the high bathymetry of the Mediterranean Sea: large islands (Corsica, Sardinia and Crete) are surrounded by deep marine pits and only coastal islands were connected to the continents during glacial ages (Shackleton et al., 1984).

In our analysis, Sicilian and Corsican samples are clustered in the same subclade (IId; Figure 2) suggesting that both islands were colonized from the same eastern genetic group. Moreover, the low nucleotide diversity and high haplotype variability (Table 2) observed for this grouping as well as the unimodal mismatch distribution (Figure 3c) are indicative of population growth from a small number of individuals (founder effect). These results thus support the hypothesis of a recent introduction on both islands, which is compatible with the hypothesis of colonization through human activity. Similar to the ferret (Mustela putorius furo), which has been used for centuries for hunting purposes in western Europe, the weasel may be considered as an 'anthropophilous' species (Vigne, 1999 and references herein). As a matter of fact, it was used as a house animal (to preserve food from small rodents; Masseti, 1995) as well as for food, fur and even traditional medicine as is still the case in Morocco. The weasel was thus part of human activities and as such was involved in the Holocene immigration wave that colonized Mediterranean islands 
with man. It is also possible that in Sicily, introduced weasels replaced some autochthonous lineage because the remains from $M$. nivalis are documented in the Terminal Pleistocene (Masseti, 1995).

As supported by Mesolithic sites in Sardinia and Corsica, the early human settlements on large Mediterranean islands are dated approximately 11000 before present (Vigne, 1999). However, the main wave of island colonization started with the Neolithic age, that is from the seventh millennium, while the permanent colonization of Corsica was realized during the sixth millennium. These dates are more recent than the $18 \mathrm{kyr}$ (95\% HPD: $1.2-48 \mathrm{kyr}$ ) we obtained from analyses of individuals from Corsica and Sicily (Table 3). In spite of a large CI, dating obtained for the time of expansion (10 kyr, 95\% HPD: 5-120 kyr) remains more compatible with an early human intervention than by a colonization initiated by the Phoenician or Greek civilizations that started about 3 kyr ago (De Marinis and Masseti, 2003; Costa, 2004) in the whole Mediterranean region.

\section{Colonization of North Africa}

Weasels from Morocco are included in clade II (subclade IIe; Figure 2a) with insular and eastern-European samples and thus do not belong to the same group as westernEuropean (Iberian, French or Italian) weasels. This result suggests that, like insular individuals, those in Morocco originated from the eastern part of Europe. Different routes have been proposed to explain colonization of North Africa (Dobson and Wright, 2000). The absence of genetic similarity between Iberian and Moroccan samples strongly suggests that North African weasels do not come from western Europe (route 1 in Dobson and Wright, 2000). Colonization through this route is, however, advocated for other mammals, including the woodmouse (Apdodemus sylvaticus), which colonized Morocco from the Iberian peninsula (Michaux et al., 2003).

Neutrality tests (Table 2; Figure 3d) performed on Moroccan samples are not indicative of recent population expansion, and nucleotide diversity is at least twice that seen in insular samples (Table 2). Although the number of analysed samples is low, these results suggest that North African populations did not undergo a recent bottleneck. With dating analyses, we obtained $28 \mathrm{kyr}$ (95\% HPD: 1.3-78 kyr) for the time of divergence of the Moroccan population, which is slightly older than estimations obtained for Sicilian and Corsican populations (18 kyr, 95\% HPD: 1.4-49 kyr). However, considering the large CI, it is difficult to determine whether colonization occurred through human movements or naturally from the middle-eastern area along the northern coast of Africa (route 2 in Dobson and Wright, 2000). To corroborate the hypothesis of an eastern route of colonization, it would be very interesting to include weasel samples from Egypt (from the Nile delta). These weasels comprise the most eastern African population and are described as a different subspecies (M. $n$. subpalmata; Reig, 1997) or even a distinct species ( $M$. subpalmata; Zyll De Jong, 1992), representing a glacial relict (Dayan and Tchernov, 1988).

\section{Taxonomic considerations}

The extreme variability of weasel morphological characteristics (body size, pattern of colouration, but also sexual, seasonal and geographic variation) led to the description of numerous taxonomic forms (and thus subspecies). Most recent studies on weasel taxonomy recognize 3-4 subspecies in the western-Palaearctic region (Frank, 1985; Zyll De Jong, 1992; Abramov and Baryshnikov, 2000; Zima and Cenevova, 2002), but there is no consensus about the geographic range or the evolutionary history of these taxa. Instead of arbitrarily adopting one particular taxonomic classification, we preferred to revert to the type locality (Sheffield and King, 1994) in which the different subspecies were originally described: (i) M. nivalis nivalis: 1776 'Province of Vesterbotten, Sweden'; (ii) M. nivalis vulgaris: 1777 'near Leipzig, Germany'; (iii) M. nivalis boccamela: 1800 'Sardinia' and (iv) M. nivalis numidica: 1855 'Tangier, Morocco'. Our mitochondrial data lead to the recognition of two main phylogenetic groups in the westernPalaearctic region (I and II on Figure 2) and the attempt to compare them with assumed subspecies constitutes only a preliminary approach to the revision of weasel taxonomic classification. As individuals from Germany fall within group I, we might assign this clade to the vulgaris group, which would thus include the whole western Europe. There is no genetic evidence for the occurrence of two subspecies in Morocco (numidica) and Sardinia (boccamela) because these samples belong to the same genetic clade (II). Finally, the identification of the nivalis subspecies would necessitate analysing weasels from Scandinavia, and in particular Sweden. In any case, linking morphotypes to genetic lineages would require concurrent analyses of the same individuals for both morphological and molecular characteristics (including nuclear markers). Such studies remain unfortunately rare in the literature, especially for carnivores, because of the inherent logistical complexities therein.

\section{Conflict of interest}

The authors declare no conflict of interest.

\section{Acknowledgements}

We are very grateful to all generous donors for providing weasel tissue samples. We also thank Johan Michaux for helpful discussion, Christelle Tougard for comments on the earlier draft of the manuscript and Sabrina McGraw for English assistance. We also appreciated the constructive comments of three anonymous referees. This work was financially supported by the PPF-EPHE 'Populations Insulaires et Fractionnées'

\section{References}

Abramov AV, Baryshnikov GF (2000). Geographic variation and intraspecific taxonomy of weasel Mustela nivalis (Carnivora, Mustelidae). Zoosyst Ross 8: 365-402.

Alcover JA, Jaume D (1983). Sobre el mostel Mustela nivalis linnaeus 1758 de les Balears (Carnivora, Mustelidae). Bol Soc Hist Nat Balears 27: 145-164.

Alder GH, Levins R (1994). The island syndrome in rodent populations. Q Rev Biol 69: 473-490.

Arnason U, Gullberg A, Janke A (1997). Phylogenetic analyses of mitochondrial DNA suggest a sister group relationship between Xenarthra (Edentata) and ferungulates. Mol Biol Evol 14: 762-768. 
Beaucournu JC, Grulich I (1968). A propos de la Belette de Corse. Mammalia 32: 341-371.

Bhagwat SA, Willis KJ (2008). Species persistence in northerly glacial refugia of Europe: a matter of chance or biogeographical traits? J Biogeogr 35: 464-482.

Blondel J, Vigne JD (1993). Space, time, and man as determinants of diversity of birds and mammals in the Mediterranean region. In: Ricklefs RE, Schulter D (eds). Species Diversity in Ecological Communities-Historical and Geographical Perspectives. The University of Chicago press: Chicago. pp. 135-146.

Bover P, Alcover JA (2008). Extinction of the autochthonous small mammals of Mallorca (Gymnesic islands, western Mediterranean) and its ecological consequences. J Biogeogr 35: 1112-1122.

Brandley MC, Schmitz A, Reeder TW (2005). Partitioned Bayesian analyses, partition choice, and the phylogenetic relationships of scincid lizards. Syst Biol 54: 373-390.

Brunhoff C, Galbreath KE, Fedorov VB, Cook JA, Jaarola M (2003). Holarctic phylogeography of the root vole (Microtus oeconomus): implications for late Quaternary biogeography of high latitudes. Mol Ecol 12: 957-968.

Clement M, Posada D, Crandall KA (2000). TCS: a computer program to estimate gene genealogies. Mol Ecol 9: 1657-1659.

Cosson JF, Hutterer R, Libois R, Sara M, Taberlet P, Vogel P (2005). Phylogeographical footprints of the Strait of Gibraltar and Quaternary climatic fluctuations in the western Mediterranean: a case study with the greater white-toothed shrew, Crocidura russula (Mammalia: Soricidae). Mol Ecol 14: $1151-1162$.

Costa JL (2004). Corse préhistorique Peuplement d'une île et mode de vie des sociétés insulaires (Ixè-II millénaires av JC). Errance edn: Paris.

Davison A, Birks JDS, Brookes RC, Messenger JE, Griffiths HI (2001). Mitochondrial phylogeography and population history of pine martens Martes martes compared with polecats Mustela putorius. Mol Ecol 10: 2479-2488.

Davison A, Birks JDS, Griffiths HI, Kitchener AC, Biggins D, Butlin RK (1999). Hybridization and the phylogenetic relationship between polecats and domestic ferrets in Britain. Biol Conserv 87: 155-161.

Dayan T, Tchernov E (1988). On the 1st occurrence of the common weasel (Mustela nivalis) in the fossil record of Israel. Mammalia 52: 165-168.

De Marinis AM (1996). The weasel Mustela nivalis in the Mediterranean region: a morphometrical approach. Vie Milieu 46: 376.

De Marinis AM, Masseti M (2003). The weasel (Mustela nivalis) on the Mediterranean islands. Mamm Biol 68: 181-186.

Dobson M, Wright A (2000). Faunal relationships and zoogeographical affinities of mammals in north-west Africa. J Biogeogr 27: 417-424.

Drummond AJ, Rambaut A (2007). BEAST: Bayesian evolutionary analysis by sampling trees. BMC Evol Biol 7: 214.

Dubey S, Cosson JF, Magnanou E, Vohralik V, Benda P, Frynta D et al. (2007a). Mediterranean populations of the lesser whitetoothed shrew (Crocidura suaveolens group): an unexpected puzzle of Pleistocene survivors and prehistoric introductions. Mol Ecol 16: 3438-3452.

Dubey S, Cosson JF, Vohralik V, Krystufek B, Diker E, Vogel P (2007b). Molecular evidence of Pleistocene bidirectional faunal exchange between Europe and the near east: the case of the bicoloured shrew (Crocidura leucodon, Soricidae). J Evol Biol 20: 1799-1808.

Dubey S, Koyasu K, Parapanov R, Ribi M, Hutterer R, Vogel P (2008). Molecular phylogenetics reveals Messinian, Pliocene, and Pleistocene colonizations of islands by north African shrews. Mol Phylogenet Evol 47: 877-882.

Fernandes CA, Ginja C, Pereira I, Tenreiro R, Bruford MW, Santos-Reis M (2008). Species-specific mitochondrial DNA markers for identification of non-invasive samples from sympatric carnivores in the Iberian Peninsula. Conserv Genet 9: 681-690.

Ferrando A, Ponsa M, Marmi J, Domingo-Roura X (2004). Eurasian otters, Lutra lutra, have a dominant mtDNA haplotype from the Iberian Peninsula to Scandinavia. J Hered 95: 430-435.

Fleming MA, Cook JA (2002). Phylogeography of endemic ermine (Mustela erminea) in southeast Alaska. Mol Ecol 11: 795-807.

Frank F (1985). On the evolution and systematics of the weasels (Mustela nivalis L). J Mamm Biol 50: 208-225.

$\mathrm{Fu}$ YX (1997). Statistical tests of neutrality of mutations against population growth, hitchhiking and background selection. Genetics 147: 915-925.

Guindon S, Gascuel O (2003). A simple, fast, and accurate algorithm to estimate large phylogenies by maximum likelyhood. Syst Biol 52: 696-704.

Hassanin A, Pasquet E, Vigne J-D (1998). Molecular systematics of the subfamily Caprinae (Artiodactyla, Bovidae) as determined from cytochrome b sequences. J Mamm Evol 5: 217-236.

Hewitt G (2000). The genetic legacy of the Quaternary ice ages. Nature 405: 907-913.

Hewitt GM (2004). Genetic consequences of climatic oscillations in the Quaternary. Philos Trans Roy Soc B 359: 183-195.

Ho SYW (2007). Calibrating molecular estimates of substitution rates and divergence times in birds. J Avian Biol 38: 409-414.

Holderegger R, Thiel-Egenter C (2009). A discussion of different types of glacial refugia used in mountain biogeography and phylogeography. J Biogeogr 36: 476-480.

Hosoda T, Suzuki H, Harada M, Tsuchiya K, Han SH, Zhang YP et al. (2000). Evolutionary trends of the mitochondrial lineage differentiation in species of genera Martes and Mustela. Genes Genet Syst 75: 259-267.

Jaarola M, Searle JB (2002). Phylogeography of field voles (Microtus agrestis) in Eurasia inferred from mitochondrial DNA sequences. Mol Ecol 11: 2613-2621.

Keane TM, Creevey CJ, Pentony MM, Naughton TJ, Mclnerney JO (2006). Assessment of methods for amino acid matrix selection and their use on empirical data shows that ad hoc assumptions for choice of matrix are not justified. BMC Evol Biol 6: 29 .

Kotlik P, Deffontaine V, Mascheretti S, Zima J, Michaux JR, Searle JB (2006). A northern glacial refugium for bank voles (Clethrionomys glareolus). Proc Natl Acad Sci USA 103: 14860-14864.

Kurose N, Abramov AV, Masuda R (2000). Intrageneric diversity of the cytochrome $\mathrm{b}$ gene and phylogeny of Eurasian species of the genus Mustela (Mustelidae, Carnivora). Zool Sci 17: 673-679.

Kurose N, Abramov AV, Masuda R (2005). Comparative phylogeography between the ermine Mustela erminea and the least weasel $M$ nivalis of Palaearctic and Nearctic regions, based on analysis of mitochondrial DNA control region sequences. Zool Sci 22: 1069-1078.

Kurose N, Masuda R, Yoshida MC (1999). Phylogeographic variation in two mustelines, the least weasel Mustela nivalis and the ermine $M$ erminea of Japan, based on mitochondrial DNA control region sequences. Zool Sci 16: 971-977.

Lebarbenchon C, Poitevin F, Montgelard C (2006). Genetic variation of the weasel (Mustela nivalis) in Corsica based on mitochondrial control region sequences. Mamm Biol 71: 164-171.

Lister AM (2004). The impact of Quaternary ice ages on mammalian evolution. Philos Trans Roy Soc B 359: 221-241.

Maddison WP, Knowles LL (2006). Inferring phylogeny despite incomplete lineage sorting. Syst Biol 55: 21-30.

Marmi J, Lopez-Giraldez F, MacDonald DW, Calafell F, Zholnerovskaya E, Domingo-Roura X (2006). Mitochondrial DNA reveals a strong phylogeographic structure in the badger across Eurasia. Mol Ecol 15: 1007-1020. 
Marra AC (2005). Pleistocene mammals of Mediterranean islands. Quatern Int 129: 5-14.

Martinkova N, McDonald RA, Searle JB (2007). Stoats (Mustela erminea) provide evidence of natural overland colonization of Ireland. Proc $R$ Soc B 274: 1387-1393.

Masseti M (1995). Quaternary biogeography of the Mustelidae family on the Mediterranean islands. Hystrix 7: 17-34.

Masseti M (1998). Holocene endemic and anthropochorous wild mammals of the Mediterranean islands. Anthropozoologica 28: 3-20.

Meia J-S, Mermod C (1992). Taxonomie et variation de taille des hermines et des belettes en Europe: revue de littérature et commentaire. Rev Suisse Zool 99: 109-118.

Michaux JR, De Bellocq JG, Sara M, Morand S (2002). Body size increase in insular rodent populations: a role for predators? Global Ecol Biogeogr 11: 427-436.

Michaux JR, Libois R, Davison A, Chevret P, Rosoux R (2004). Is the western population of the European mink, (Mustela lutreola), a distinct Management Unit for conservation? Biol Conserv 15: 357-367.

Michaux JR, Libois R, Filippucci MG (2005). So close and so different: comparative phylogeography of two small mammal species, the yellow-necked fieldmouse (Apodemus flavicollis) and the woodmouse (Apodemus sylvaticus) in the western Palearctic region. Heredity 94: 52-63.

Michaux JR, Magnanou E, Paradis E, Nieberding C, Libois R (2003). Mitochondrial phylogeography of the woodmouse (Apodemus sylvaticus) in the western Palearctic region. Mol Ecol 12: 685-697.

Montgelard C, Bentz S, Tirard C, Verneau O, Catzeflis FM (2002). Molecular systematics of Sciurognathi (Rodentia): the mitochondrial cytochrome $b$ and $12 S$ rRNA genes support the Anomaluroidea (Pedetidae and Anomaluridae). Mol Phylogenet Evol 22: 220-233.

Philippe H (1993). Must, a computer package of management utilities for sequences and trees. Nucleic Acids Res 21: 5264-5272.

Philippe H, Sorhannus U, Baroin A, Perasso R, Gasse F, Adoutte A (1994). Comparison of molecular and paleontological data in diatoms suggests a major gap in the fossil record. J Evol Biol 7: 247-265.

Pierpaoli M, Riga F, Trocchi V, Randi E (1999). Species distinction and evolutionary relationships of the Italian hare (Lepus corsicanus) as described by mitochondrial DNA sequencing. Mol Ecol 8: 1805-1817.

Piertney SB, Stewart WA, Lambin X, Telfer S, Aars J, Dallas JF (2005). Phylogeographic structure and postglacial evolutionary history of water voles (Arvicola terrestris) in the UK. Mol Ecol 14: 1435-1444.

Rambaut A, Drummond AJ (2007). Tracer v1.4 Release; http:// beast.bio.ed.ac.uk/Tracer.

Ramos-Onsins SE, Rozas J (2002). Statistical properties of new neutrality tests against population growth. Mol Biol Evol 19: 2092-2100.

Randi E (2007). Phylogeography of South European mammals. In: Weiss S, Ferrand N (eds). Phylogeography of Southern European Refugia. Springer: The Netherlands. pp 101-126.

Reig S (1997). Biogeographic and evolutionary implications of size variation in North American least weasels (Mustela nivalis). Can J Zool 75: 2036-2049.
Rogers AR (1995). Genetic-evidence for a Pleistocene population explosion. Evolution 49: 608-615.

Ronquist F, Huelsenbeck JP (2003). MrBayes 3: Bayesian phylogenetic inference under mixed models. Bioinformatics 19: $1572-1574$

Rozas J, Sanchez-DelBarrio JC, Messeguer X, Rozas R (2003). DnaSP, DNA polymorphism analyses by the coalescent and other methods. Bioinformatics 19: 2496-2497.

Rull V (2009). Microrefugia. J Biogeogr 36: 481-484.

Saarma U, Tumanov IL (2006). Phylogenetic evaluation of three subspecies from the Mustela nivalis group. Zool Stud 45: 435-442.

Santucci F, Emerson BC, Hewitt GM (1998). Mitochondrial DNA phylogeography of European hedgehogs. Mol Ecol 7: 1163-1172.

Sarà M (1998). I Mammiferi delle Isole del Mediterraneo. L'Epos: Palermo.

Schneider S, Roessli D, Excoffier L (2000). Arlequin, v.2.000: a software for population genetic data analysis. Genetics and Biometry Laboratory, University of Geneva, Switzerland.

Shackleton JC, Van Andel TH, Runnels CN (1984). Coastal paleogeography of the central and western Mediterranean during the last 125,000 years and its archaeological implications. J Field Arch 11: 307-314.

Sheffield SR, King CM (1994). Mustela nivalis. Mamm Species 454: $1-10$.

Sommer R, Benecke N (2004). Late- and post-glacial history of the mustelidae in Europe. Mamm Rev 34: 249-284.

Stewart JR, Lister AM (2001). Cryptic northern refugia and the origins of the modern biota. Trends Ecol Evol 16: 608-613.

Swofford DL (2002). PAUP* Phylogenetic Analysis Using Parsimony (*and Other Methods) Version 4 0b .10 ed Sinauer Associates: Sunderland, Massachusetts.

Taberlet P, Fumagalli L, Wust-Saucy AG, Cosson JF (1998). Comparative phylogeography and postglacial colonization routes in Europe. Mol Ecol 7: 453-464.

Tajima F (1989). Statistical-method for testing the neutral mutation hypothesis by DNA polymorphism. Genetics 123: 585-595.

Tougard C, Renvoisé E, Petitjean A, Quéré JP (2008). New Insight into the colonization processes of common voles: inferences from molecular and fossil evidence. PLoS One 3: e3532.

Vigne J (1999). The holocene history of the European vertebrate fauna. Archäologie in Eurasien. Deutsches Archäologisches Institut: Berlin. pp 295-322.

Vigne J, Alcover J (1985). Incidence des relations historiques entre l'homme et l'animal dans la composition actuelle du peuplement amphibien reptilien et mammalien des îles de Mediterranée occidentale. Actes Du 110ème Congrès National Des Sociétés Savantes (Montpellier, 1985), Section Sciences, fasc. II. Comité des Travaux Historiques et Scientifiques: Paris, 79-91.

Zima J, Cenevova E (2002). Coat colour and chromosome variation in central European populations of the weasel (Mustela nivalis). Folia Zool 51: 265-274.

Zyll De Jong CGV (1992). A morphometric analysis of cranial variation in Holarctic weasels (Mustela nivalis). Mamm Biol 57: 77-93.

Supplementary Information accompanies the paper on Heredity website (http://www.nature.com/hdy) 